\title{
Energy Analysis for the Compaction of Jerash Cohesive Soil
}

\author{
Talal Masoud, Hesham Alsharie, Ahmad Qasaimeh \\ Civil Engineering Department, Jerash University, Jerash, Jordan \\ Email: argg22@yahoo.com
}

Received 13 February 2015; accepted 26 March 2015; published 27 March 2015

Copyright (C) 2015 by authors and Scientific Research Publishing Inc.

This work is licensed under the Creative Commons Attribution International License (CC BY). http://creativecommons.org/licenses/by/4.0/

c) (7) Open Access

\begin{abstract}
The aim of this research is to study the effect of compaction energy on Jerash cohesive soil. Qualitative and quantitative analyses of soil compaction energy with relation to unit weight and moisture content are conducted. These analyses spot the light on energy savings performed for soil compaction. The study shows that as the compaction energy increases; the unit weight of the Jerash cohesive soil increases and the optimum water content decreases. Generally, a soil with low moisture content is less vulnerable to compaction than a soil with high moisture content. But when the moisture content is too high, all the soil pores are filled with water, so that the soil becomes less compressible where the unit weight and strength characteristics decrease. The optimum energy value and optimum water content are thus of great concern. The effect of energy on soil unit weight is very large as the energy increases from 400 to $1400 \mathrm{KJ} / \mathrm{m}^{3}$ and after that level; the effect of energy on soil unit weight is very small. Consequently, optimal compaction energy ranges from 1200 up to value $1400 \mathrm{KJ} / \mathrm{m}^{3}$, where 50 to 60 blows can be applied and the optimal correlated water content is between $14 \%-15 \%$.
\end{abstract}

\section{Keywords}

Energy, Jerash Cohesive Soil, Compaction, Jordan

\section{Introduction}

In the construction of highways, for earth dams and other engineering structures, loose soil must be compacted to increase its unit weight, and in turn increasing soil strength characteristics, increasing soil bearing capacity, and decreasing soil settlement.

The soil compaction can be defined as "the process by which the soil grains are rearranged to decrease void space and bring them into closer contact with one another, thereby, increasing the bulk density" [1]. Compaction 
or densification of soil is done by removal of air which requires mechanical energy. Sheep feet rollers, rubber tired rollers and vibratory rollers may be used for soil compaction.

Knowledge of water contents in relation to the soil compaction for a particular soil can be helpful in scheduling the routine mechanical operations on that soil [2] [3].

The soil compaction is accompanied by the removal of the soil air, changes the soil structure, and macroscopically increases the soil strength [4]. The soil compaction process is highly influenced by the soil water content [5]-[7].

Vulnerability of a soil to compaction at the given soil moisture and energy level depends also on its clay content and mineralogical characteristics [8] [9]. Generally, a soil with very low moisture content is less vulnerable to compaction than a soil with high moisture content [10]. But when the moisture content is so high that all the soil pores are filled with water, the soil becomes less compressible [8].

Bulk density (dry soil mass per unit volume) is the most frequently used parameter to characterize the soil compaction [11]. In swelling-shrinking soil, it is recommendable to determine the bulk density at the standard moisture contents [12].

\section{Methodology}

The aim of this research is to study the effect of energy on dry unit weight of Jerash cohesive soil. Consequently; qualitative and quantitative analyses of soil compaction spot the light on soil strength characteristics and energy savings performed for soil compaction.

To perform the compaction test, samples were taken from eastern area of Jerash city in Jordan. The compaction test was conducted using "Standard Proctor Test". The number of hammer blows per each layer varied from 20 blows per layer to 70 blows per layer which in turn varied the energy per unit volume.

The soil was mixed with varying amount of water and then compacted in three equal layers by hammer that delivered 20 blows to each layer. The moisture-unit weight relationship was plotted for each sample tested to obtain the maximum dry unit weight.

The same procedure was repeated with $25,30,40,50,60$, and 70 blows per layer. The optimum water content and maximum dry unit weight were obtained for each.

\section{Discussion and Analysis}

The degree of compaction of a soil is measured in terms of its dry unit weight. Many researchers studied the factors affect compaction characteristics of the soil; and they found that the soil type, grain size, grain distribution, and grain shape were of great influence on the maximum dry unit weight.

In this investigation, the effect of energy on the dry unit weight of Jerash cohesive soil was studied. The compaction energy per unit volume $\left(\mathrm{KJ} / \mathrm{m}^{3}\right)$ used for Standard Proctor Test is given by the following equation:

$$
\begin{aligned}
& \text { Energy } \\
& =\frac{(\text { Number of blows per layer }) *(\text { Number of layer }) *(\text { Weight of hammer }) *(\text { Height of drop of hammer })}{\text { Volume of mold }}
\end{aligned}
$$

To study the effect of energy on the dry unit weight of Jerash cohesive soil, samples were taken from eastern part of Jerash city. The physical properties of the soil are given in Table 1.

The soil was mixed with water and compacted in three equal layers by hammer that delivered 20 blows to each layer. The procedure was repeated with $25,30,40,50,60$, and 70 blows per layer. The optimum water content and maximum dry unit weight were obtained for each trial as shown in Figure 1 and Table 2.

While the compaction energy increases from 480 to $1680 \mathrm{KJ} / \mathrm{m}^{3}$, the dry unit weight of Jerash cohesive soil increases from 14 to $16 \mathrm{KN} / \mathrm{m}^{3}$ and the optimal water content (OWC) decreases from 26\% to 12\% (Figure 2, Figure 3). These ranges provide information about how we may manage the compaction to a wise procedure

Table 1. Physical properties of Jerash cohesive soil.
\begin{tabular}{|ccccccc}
\hline Specific Gravity & Plasticity Index & Plastic Limit & Liquid Limit & Clay & Silt & Sand \\
\hline 2.67 & $22 \%$ & $36 \%$ & $58 \%$ & $54 \%$ & $39 \%$ & $7 \%$ \\
\hline
\end{tabular}


Table 2. The results of standard Proctor test on Jerash cohesive soil.

\begin{tabular}{cccc}
\hline Number of Blows per Layer & Energy per Unit Volume $\left(\mathrm{KJ} / \mathrm{m}^{3}\right)$ & Optimum Water Content OWC \% & Unit Weight $\gamma_{\mathrm{d}}\left(\mathrm{KN} / \mathrm{m}^{3}\right)$ \\
\hline 20 & 480 & 26 & 14 \\
25 & 600 & 24 & 14.4 \\
30 & 720 & 21 & 14.7 \\
40 & 960 & 17 & 15.3 \\
50 & 1200 & 15 & 15.7 \\
60 & 1440 & 14 & 15.9 \\
70 & 1680 & 12 & 16.0 \\
\hline
\end{tabular}

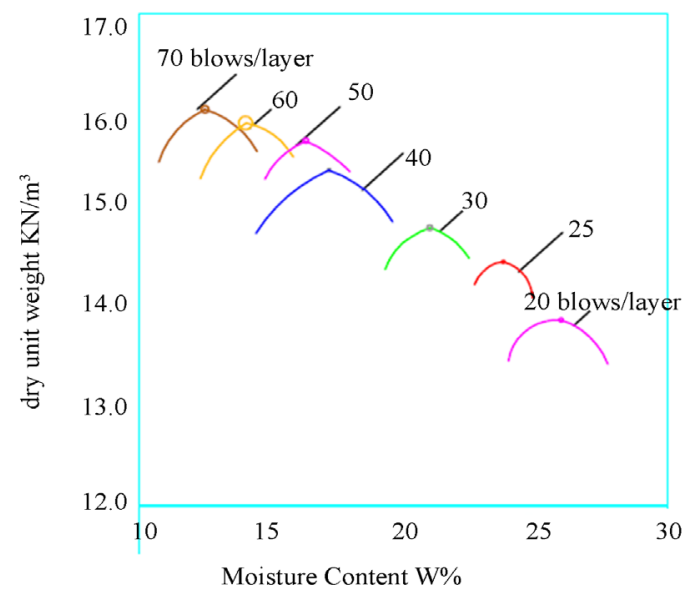

Figure 1. The values of unit weight moisture content varying within different compaction blows for Jerash soil.

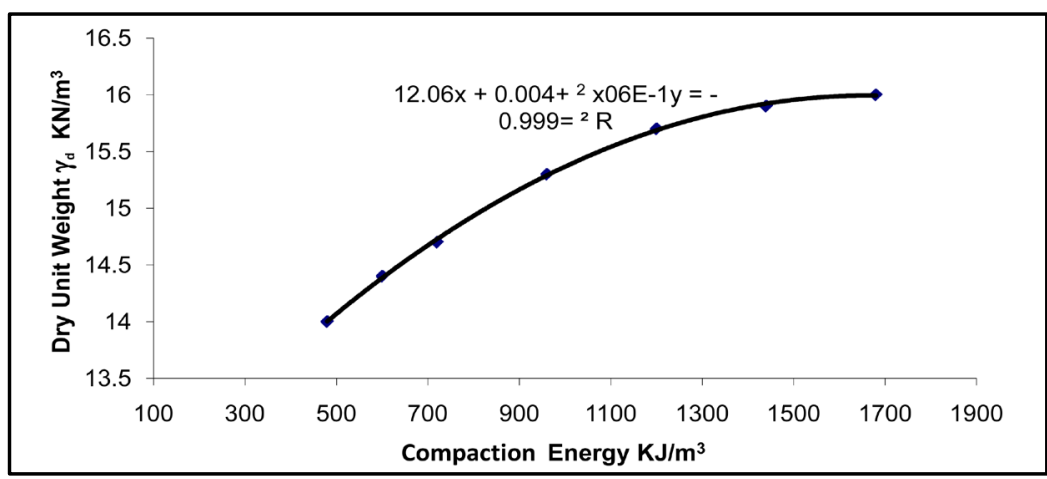

Figure 2. Relation between unit weight and compaction energy for Jerash soil.

without wasting time, effort, and energy. The effect of energy on dry unit weight is very large as the energy increase from 480 to $1400 \mathrm{KJ} / \mathrm{m}^{3}$ and after that level, the effect of energy on the unit weight is very small as shown in Figure 2.

It is worthy to recall that for certain number of blows and while increasing water content, that the soil unit weight increases to optimal value and then decreases is because the soil with low moisture content is less susceptible to compaction than the soil with high moisture content. But when the moisture content is too high, all the soil pores are filled with water, so that the soil becomes less compressible as that is interpreted previously in Figure 1. Generally, while the compaction energy increases, the unit weight of the Jerash cohesive soil increases as the optimum water content decreases. Thus optimum energy value and optimum water content are of great concern about soil unit weight, soil strength characteristics, and soil energy compaction. 


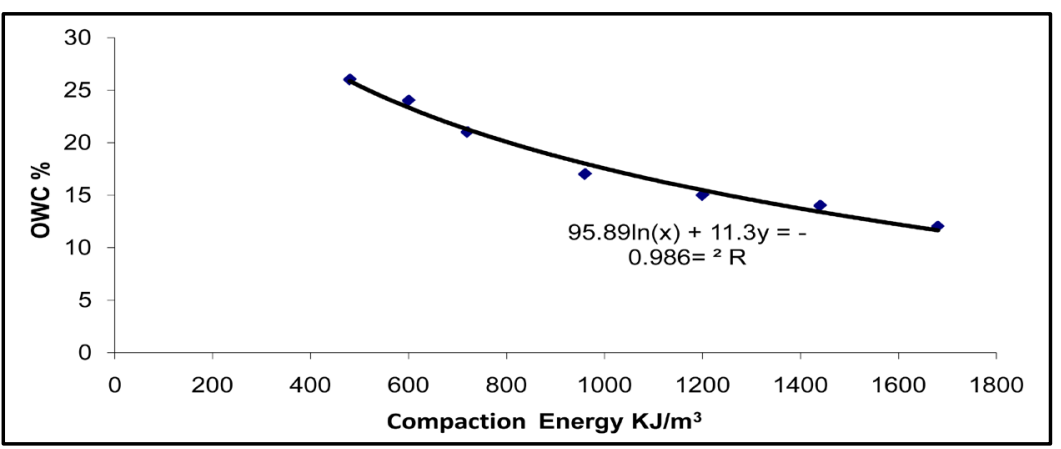

Figure 3. Relation between optimal water content and compaction energy for Jerash soil.

\section{Conclusions}

This investigation focuses on the effect of compaction energy on dry unit weight of Jerash cohesive soil. The optimum energy value and optimum water content are of great concern about soil unit weight, soil strength characteristics, and soil energy compaction.

Results on Jerash cohesive soil show that as the compaction energy increases, water content decreases, and the unit weight increases. The effect of compaction on unit weight of Jerash cohesive soil is very large as the energy varies from 400 to $1400 \mathrm{KJ} / \mathrm{m}^{3}$, and the effect after that level is very small, which means that any further compaction of Jerash cohesive soil is not wise. In fine, optimal compaction energy ranges from 1200 to 1400 $\mathrm{KJ} / \mathrm{m}^{3}$, where 50 to 60 blows can be delivered, and optimal water content is between $14 \%-15 \%$.

\section{References}

[1] SSSA (1996) Glossary of Soil Science Terms. Soil Science Society of America, Madison.

[2] Batey, T. (2009) Soil Compaction and Soil Management-A Review. Soil Use and Manage, 25, 335-345. http://dx.doi.org/10.1111/j.1475-2743.2009.00236.x

[3] Ohu, J., Folorunso, O., Adeniji, F. and Raghavan, G. (1989) Critical Moisture Content as an Index of Compactibility of Agricultural Soils in Borno State of Nigeria. Soil Technology, 2, 211-219. http://dx.doi.org/10.1016/0933-3630(89)90007-X

[4] Taylor, H.M. (1971) Effects of Soil Strength on Seedling Emergence, Root Growth and Crop Yield. In: Barnes, K.K., Carleton, W.M., Taylor, H.M., Throckmorton, R.I. and van den Berg, G.E., Eds., Compaction of Agricultural Soils, American Society of Agricultural Engineers, St. Joseph, 292-305.

[5] Hamza, M.A. and Anderson, W.K. (2005) Soil Compaction in Cropping Systems. A Review of the Nature, Causes and Possible Solutions. Soil and Tillage Research, 82, 121-145. http://dx.doi.org/10.1016/j.still.2004.08.009

[6] Horn, R., Doma, H., Sowiska-Jurkiewicz, A. and van Ouwerkerk, C. (1995) Soil Compaction Processes and Their Effects on the Structure of Arable Soils and the Environment. Soil and Tillage Research, 35, 23-36. http://dx.doi.org/10.1016/0167-1987(95)00479-C

[7] Mosaddeghi, M., Hajabbasi, M., Hemmat, A. and Afyuni, M. (2000) Soil Compactibility as Affected by Soil Moisture Content and Farmyard Manure in Central Iran. Soil and Tillage Research, 55, 87-97. http://dx.doi.org/10.1016/S0167-1987(00)00102-1

[8] Smith, C.W., Johnston, M.A. and Lorentz, S. (1997) Assessing the Compaction Susceptibility of South African Forestry Soils. I. The Effect of Soil Type, Water Content and Applied Pressure on Uni-Axial Compaction. Soil and Tillage Research, 41, 53-73. http://dx.doi.org/10.1016/S0167-1987(96)01084-7

[9] Wakindiki, I. and Ben-Hur, M. (2002) Soil Mineralogy and Texture Effects on Crust Micromorphology, Infiltration, and Erosion. Soil Science Society of America Journal, 66, 897-905. http://dx.doi.org/10.2136/sssaj2002.8970

[10] Gysi, M., Ott, A. and Flühler, H. (1999) Influence of Single Passes with High Wheel Load on a Structured, Unploughed Sandy Loam Soil. Soil and Tillage Research, 52, 141-151. http://dx.doi.org/10.1016/S0167-1987(99)00066-5

[11] Panayiotopoulos, K.P., Papadopoulou, C.P. and Hatjiioannidou, A. (1994) Compaction and Penetration Resistance of an Alfisol and Entisol and Their Influence on Root Growth of Maize Seedlings. Soil and Tillage Research, 31, 323-337. http://dx.doi.org/10.1016/0167-1987(94)90039-6

[12] Håkansson, I. and Lipiec, J. (2000) A Review of the Usefulness of Relative Bulk Density Values in Studies of Soil Structure and Compaction. Soil and Tillage Research, 53, 71-85. http://dx.doi.org/10.1016/S0167-1987(99)00095-1 